\title{
Neonatal Deformity
}

National Cancer Institute

\section{Source}

National Cancer Institute. Neonatal Deformity. NCI Thesaurus. Code C50666.

A cong enital anatomic abnormality manifested during the neonatal period. 